\title{
WYCHOWANIE W SPOŁECZNOŚCI ŻYDOWSKIEJ W ŚWIETLE NAKAZÓW RELIGIJNYCH
}

\author{
KatARZYNA RYGiEL \\ k_rygiel87@interia.pl
}

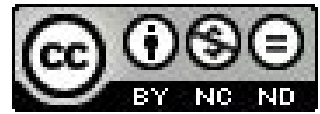

Rozpoczynając rozważania na temat tradycyjnej rodziny żydowskiej, opieram się na założeniu o ortopraksji judaizmu. Za postępowanie właściwe i pożądane w społeczności uważa się postępowanie zgodne z nakazami prawa, więc manifestacją prawdziwej wiary winno być odpowiednie działanie ${ }^{1}$. Przyjęcie takiego założenia skutkuje skupieniem uwagi na rozstrzygnięciach prawnych, które normują życie wyznawców judaizmu.

Z tego też względu warto w tym miejscu przywołać i pokrótce scharakteryzować najważniejsze dla żydowskiego prawa księgi. Podstawą jest Tora, czyli Pięcioksiag Mojżeszowy, obejmujący pierwsze pięć ksiąg Biblii i będący źródłem kształtowania się żydowskiej tożsamości. „Prawo Mojżeszowe jest rdzeniem danym ludowi Izraela na górze Synaj i do chwili obecnej obowiązującym potomków tych, którzy tam byli"2

Liczne objaśnienia Tory i refleksje nad nią doprowadziły do powstania kolejnej przełomowej księgi, a w zasadzie to dwóch ksiąg, znanych pod nazwą Talmudu. Pierwszą z nich jest Miszna - kompilacja żydowskich praw spisana według tradycji przez Rabbiego Jehudę HaNassiego. Zawiera ona w sobie tzw. Torę Ustnq, a więc tradycje które zostały dane podczas Objawienia pod górą Synaj, ale dotąd nauczane były ustnie ${ }^{3}$.

Pierwotnie Miszna miała stanowić przypomnienie dla studentów, którzy przekaz Tory Ustnej otrzymywali bezpośrednio od swoich nauczycieli, jednak z upływem czasu i pogłębiającym się rozproszeniem żydowskiego narodu, przestała ona spełniać swoją funkcję i stała się dla większości niezrozumiała. Dlatego też mędrcy - a zwłaszcza Raw Aszi i Rawina, postanowili stworzyć Gemarę - a więc wielkie studium Miszny, które poprzez analizę jej treści stara się przede wszystkim odnajdywać połączenia między tekstem biblijnym a orzeczeniem Miszny

Oprócz tych podstawowych pozycji istnieje jeszcze ogromna ilość literatury midraszowej, komentarzy biblijnych i prawnych, kodeksów i respons pisanych przez autorytety rabiniczne. Należy zatem pamiętać, że każdy z tych utworów ma dla religijnych Żydów znaczenie przede wszystkim, jako tekst ciągle żywy i o różnym stopniu świętości, do którego można sięgnać, gdy trzeba rozstrzygnąć spór; tekst, z którego czerpie się znajomość zasad moralnych i rytuału; i w końcu tekst, który stanowi autorytatywny drogowskaz w życiu.

Jak więc widać, judaizm nie bez powodu nazywany jest religią prawa, bo jak pisze rabin S. Pecaric: „W przestrzeganiu sześciuset trzynastu micwot, a nie w swobodnych dywagacjach o Bogu zawiera się jego istota" ${ }^{\prime \prime}$.

Przepisy prawa religijnego regulują w zasadzie cały obszar życia społecznego, a że jego podstawąjest rodzina, Talmud strzeże jej czystości i stabilności za pomocą licznych wskazówek i przy-

\footnotetext{
A. Szwed, Ta, która spogląda na króla. Rola kobiety w tradycyjnym judaizmie, [w:] K. Leszczyńska, A. Kościańska (red.), Kobiety i religie, Kraków 2006, s. 15.

H. Wouk, To jest mój Bóg. Judaizm: wiara, prawo, etyka, Warszawa 2002, s. 170.

I. Rapoport, Egzegeza żydowska okresu biblijnego i rabinicznego, [w:] M. Rosik (red.), Wprowadzenie do literatury i egzegezy żydowskiej okresu biblijnego i rabinicznego, Wrocław 2009, s. 231.

4 Tamże, s. 248-249.

5 S. Pecaric (red.), Bramy Halachy. Religijne Prawo żydowskie, Kraków 2005, s. 27.
} 
powieści. Żydowska rodzina tradycyjnie bywa postrzegana jako miniatura świątyni i podstawowa religijna instytucja, która przekazuje swoim członkom komunikat, że pełne spełnienie mogą znaleźć jedynie w ramach życia małżeńskiego i rodzinnego $0^{6}$. Taka postawa swoim szerszym oddziaływaniem wpływała na stabilność całej żydowskiej społeczności. Także Talmud z naciskiem podkreśla: „Osoba nie pozostająca w małżeństwie żyje bez radości, bez błogosławieństwa i bez dobra"7. Głównym celem małżeństwa jest założenie rodziny, więc kwestia sprowadzenia na świat licznego potomstwa, zwłaszcza płci męskiej, staje się kluczowa dla małżonków. Nakaz prokreacji odnajdujemy już w Księdze Rodzaju (1,28): „Bądźcie płodni i rozmnażajcie się, abyście zaludnili ziemię i uczynili ją sobie poddaną" ${ }^{\prime \prime}$. Z kolei talmudyczny traktat Jewamot wskazuje, że mężczyzna, który nie spełnia owego przykazania, powinien być traktowany na równi z morderca, ponieważ pomniejsza on swój ślad na ziemi . Jak wynika z przytoczonych fragmentów jest to nakaz ciążący przede wszystkim na mężczyznach. Dlatego też jeśli mężczyzna, który był żonaty z kobietą przez dziesięć lat i nie doczekał się potomstwa, powinien według Talmudu rozwieść się z nią i poślubić inną kobietę, z którą będzie mógł spełnić nakaz prokreacji. Jeśli z kolei kobieta znajdzie się w podobnej sytuacji, może zwrócić się do sądu rabinicznego z prośbą o wymuszenie na mężu rozwodu, jeśli on sam dotąd się na to nie zdecydowa $1^{10}$. W Talmudzie znajdujemy wiele fragmentów wskazujących, że urodzenie syna zdecydowanie przedkłada się nad urodzeniem córki. Wynika to między innymi z faktu, że chłopiec w przyszłości będzie mógł pełnić w gminie żydowskiej istotne funkcje nieosiagalne dla kobiet, ponadto syn był dla rodziców gwarancją podpory na starość. Często cytowany fragment Talmudu mówi na ten temat: „Jest niemożliwe, aby świat mógł istnieć bez mężczyzn i kobiet. Szczęśliwy jednak, kto ma męskie potomstwo, a nieszczęsny człowiek, którego dzieci są córkami" ${ }^{\prime 11}$. Inny ustęp z Talmudu tłumaczy, dlaczego córka nie jest tak upragniona i jak wiele uwagi wymaga od ojca: „Córka to fałszywy skarb dla ojca. Z niepokoju o nią nie śpi po nocach; $w$ dzieciństwie, by nie została uwiedziona, $w$ młodości, by nie zeszła na manowce, $\mathrm{w}$ wieku małżeńskim, że nie znajdzie męża, gdy jest mężatka, by nie była bezpłodna, a na starość, by nie uprawiała czarów"12. Można odnaleźć także inne, mniej jednostronne poglądy, jednak żaden z nich nie neguje względnej wyższości dziecka płci męskiej. Te różnice znajdują także odzwierciedlenie w rytuałach towarzyszących narodzinom chłopca i dziewczynki, a także w późniejszym okresie przy wprowadzaniu ich do pełnego uczestnictwa w społeczności. Przykładem może być uroczysta ceremonia obrzezania brit mila dokonywana 8. dnia życia chłopca lub też pidion ha-ben, czyli składanie okupu za pierworodnego syna, gdy ten ukończy 30 dni życia. Natomiast kiedy na świat przychodzi dziewczynka, nic takiego się nie dzieje ${ }^{13}$. Podobnie sytuacja wygląda, gdy dzieci zbliżają się do osiągnięcia wieku dorosłego - zgodnie z halachą u dziewcząt jest to dwunasty rok życia, a u chłopców trzynasty. Wtedy też odbywa się obrzęd bar micwa (syn przykazania), który wprowadza chłopca w odpowiedzialne życie religijne i jest oznaką jego nowego statusu w gminie. Od tego momentu może być wliczany do minjanu (kworum dziesięciu mężczyzn wymagane przy niektórych modlitwach), wzywany

6 J. Balswick, Are American Jewish families closely knit?, [w:] B. Schlesinger (red.), The Jewish family, Toronto 1971, s. 15. A. Cohen, Talmud, Warszawa 1995, s. 174.

Pismo święte Starego i Nowego Testamentu, Poznań-Warszawa 1995, s. 25.

Z. Borzymińska, Żydowska narzeczona, żydowska żona. Obyczajowość ujęta w ramy prawa, [w:] A. Żarnowska, A. Szwarc (red.), Kobieta i małżeństwo. Społeczno-kulturowe aspekty seksualności, Warszawa 2004, s. 138.

10 R. Biale, Women and Jewish law. An Explorating of women's issues in halakhic sources, New York 1984, s. 202.

11 A. Unterman, Żydzi. Wiara i życie, Warszawa 2002, s. 135.

12 A. Cohen, Talmud..., dz. cyt., s. 183-184.

13 A. Unterman, Żydzi..., dz. cyt., s. 135-136, 140. 
do czytania Tory w synagodze, a w czasie porannej modlitwy zakłada tefilin i filakterie. Z tymi wydarzeniami i oprawą kontrastuje wejście dziewczyny w dorosłe życie - nie towarzyszy temu żadna ceremonia, od tego momentu młoda kobieta musi po prostu zacząć stosować się do przepisów, które dotąd poznała ${ }^{14}$. Ta nierówność między dzieckiem płci żeńskiej i męskiej odbija się także w ich dorosłości, poprzez różny stopień uczestnictwa w życiu społeczności i wychowywaniu potomstwa. Ojciec jako głowa rodziny ma obowiązek wychować swoje dzieci w bojaźni bożej i przekazać im wiedzę o bożym prawie. Niczym patriarcha z Pięcioksięgu jest on wybitną osobowościa, która ma za zadanie chronić, ale też dyscyplinować pozostałych domowników. Jego pomocą jest żona - nauczycielka i moralna przewodniczka rodziny. Jej obowiązki i odpowiedzialność związane są nieprzerwanie ze sferą domową ${ }^{15}$.

Rodzice mogą odnaleźć w Talmudzie wiele cennych wskazówek dotyczących odpowiednich metod wychowawczych, np.: „CZłowiek nigdy nie powinien mówić dziecku, że coś mu da, i nie dotrzymywać obietnicy, ponieważ w ten sposób uczy je kłamstwa”"16. Kolejny fragment „Nie wolno nigdy wyróżniać żadnego z dzieci"17, został zaczerpnięty z biblijnej opowieści o Józefie i Jakubie, która pokazuje jakie mogą być konsekwencje faworyzowania jednego z dzieci. Przepisy talmudyczne starają się również wskazać rodzicom złoty środek między zbytnią pobłażliwością a surowym karaniem dzieci: „,Jeśli zaniechasz wymierzenia dziecku kary, w końcu stanie się ono skrajnie zdeprawowane” - i z drugiej strony - „Nie powinno się trzymać dzieci zbyt krótko”18.

Aby rodzice mogli wypełniać efektywnie swoje obowiązki wobec potomstwa, konieczne jest oparcie funkcjonowania rodziny na mocnych fundamentach zaczerpniętych właśnie z pism Talmudu. B. Schlesinger ${ }^{19}$ wskazuje na cztery podstawowe wartości temu służące, które rządziły życiem żydowskiej rodziny przez wieki i rządzą nadal. Pierwsza, nazywana taharath mishpacha - „czystość rodziny” - dotyczy sfery kontaktów seksualnych małżonków. W przepisach można odnaleźć pewną ambiwalencję - z jednej strony hołdują poglądom ascetycznym, a z drugiej wskazują na akt płciowy jako dobrą siłę w życiu i dar od Boga. Wynika to z faktu, że jedynie ujęta w ramy rodziny seksualność, może stanowić podstawę stabilnego porząadku społecznego, gdyż jest wtedy wypełnieniem dwóch istotnych micw - prokreacji i onah (praw regulujących obowiązki męża wobec żony). Jednak gdy popęd seksualny próbuje uwolnić się z tych ram, jest postrzegany i opisywany jako zły impuls ${ }^{20}$.

Druga wartość nazwana jest gidul uboneth, co możemy tłumaczyćjako obowiązek odpowiedniego wychowania dziecka i wykształcenia u niego wartościowych z punktu widzenia społeczności postaw. Bardzo mocnym imperatywem jest tu skrupulatna dbałość o fizyczne, socjalne, edukacyjne i religijne potrzeby dziecka. Jest to odpowiedzialność spoczywająca przede wszystkim na rodzicach, inni ludzie czy instytucje mogą tylko ich w tym wspierać. To rodzice są zawsze dla swojego potomstwa najbardziej wpływowymi nauczycielami, są więc zobligowani do dawania im przykładu - swoim zachowaniem, swoimi relacjami z innymi ludźmi, udziałem w życiu społeczności, a przede wszystkim w wypełnianiu nakazów religijnych. Nie bez powodu więc Talmud przestrzega rodziców: „Mowa dziecka na ulicy jest mową jego ojca i matki”21.

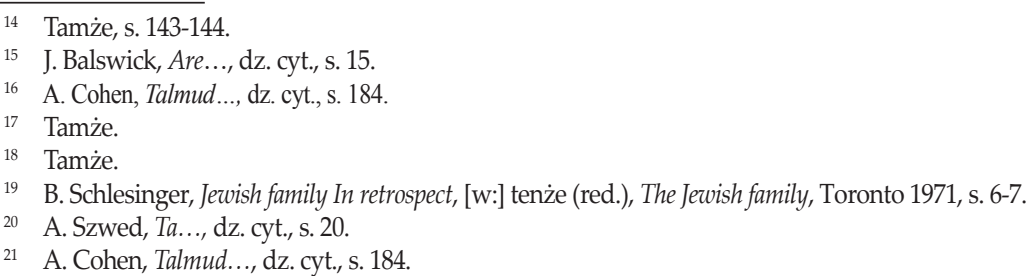


Kolejną wartością jest tzw. „synowska odpowiedzialność” - kibud av vo-em. Mówi nam ona o tym, że dziecko jest nie tylko przedmiotem czułej rodzicielskiej opieki, ale również ma przypisane pewne powinności. Szczególnie dotyczy to obowiązku czczenia i szanowania rodziców, tak długo, jak żyją i odnoszenia się do nich z pewną dozą bojaźni. Talmud definiuje to następująco: „Przez bojaźń rozumiano, że syn nie przejmuje roli ojca, nie zasiada na jego miejscu, nie zaprzecza jego słowom i nie podejmuje decyzji wbrew jego opinii. Przez cześć rozumiano, że zapewnia mu pożywienie, picie, ubranie i schronienie, pomaga mu zawsze i we wszystkim"22. Taka postawa wynika z założenia, że rodzice będą tak godni swojej pozycji i wierni obowiązkom, że zasługują w pełni na takie honorowanie ich autorytetu. Dla potomstwa, jest to więc stałe wyzwanie - aby spłacić zaciagnięty u rodziców dług, nawet kiedy są już ludźmi w bardzo podeszłym wieku, a po śmierci podtrzymywać pamięć o nich. Jednak zgodnie z prawem talmudycznym synowskie posłuszeństwo w pierwszej kolejności przysługuje ojcu: „Porzuć nakaz oddawania czci matce i obsłuż ojca, albowiem zarówno ty, jak i twoja matka macie obowiązek okazywać mu cześć' ${ }^{\prime \prime 2}$.

Czwartą wartością wspierającą życie rodzinne jest shalom bayith - „domowy pokój”. Z jednej strony dom rodzinny powinien dawać każdemu z członków możliwość rozwoju i ekspresji swojej osobowości. Jednak z drugiej strony patrząc, konieczne jest, aby każdy w jednakowym stopniu doświadczał poczucia solidarności i bycia częścią większej i mającej ogromne znaczenie jedności, jaką jest cała społeczność. Rodzina staje się więc dla każdego Żyda pomostem łączącym go z resztą wyznawców judaizmu. Dlatego też tak wiele uwagi poświęca się dzieciom i ich wychowaniu - zarówno w pismach, jak i w praktyce życia codziennego. To one są gwarancją istnienia społeczności, a ich właściwe przysposobienie do uczestnictwa w niej, daje nadzieję na przetrwanie tradycji i religijnego dziedzictwa. Co charakterystyczne dla judaizmu, obowiązki rodzicielskie nie są odbierane jedynie indywidualnie $\mathrm{w}$ stosunku do roli ojca czy matki, ale są w mocnym związku z ich odpowiedzialnością wobec społeczności. To ona w przyszłości ich rozliczy i oceni, czy sumiennie się z nich wywiązali, przyczyniając się w ten sposób do zwiększenia jej bezpieczeństwa i dobrobytu.

\section{Bibliografia}

Balswick J., Are American Jewish families closely knit?, [w:] B. Schlesinger (red.), The Jewish family, Toronto 1971.

Biale R., Women and Jewish law. An Explorating of women's issues in halakhic sources, New York 1984.

Borzymińska Z., Żydowska narzeczona, żydowska żona. Obyczajowość ujęta w ramy prawa, [w:] A. Żarnowska, A. Szwarc (red.), Kobieta i małżeństwo. Społeczno-kulturowe aspekty seksualności, Warszawa 2004.

Cohen A., Talmud, Warszawa 1995.

Pecaric S. (red.), Bramy Halachy. Religijne Prawo żydowskie, Kraków 2005.

Pismo święte Starego i Nowego Testamentu, Poznań-Warszawa 1995.

Rapoport I., Egzegeza żydowska okresu biblijnego i rabinicznego, [w:] M. Rosik (red.), Wprowadzenie do literatury i egzegezy żydowskiej okresu biblijnego i rabinicznego, Wrocław 2009.

Schlesinger B., Jewish family In retrospect, [w:] tenże (red.), The Jewish family, Toronto 1971.

Szwed A., Ta, która spoglada na króla. Rola kobiety w tradycyjnym judaizmie, [w:] K. Leszczyńska, A. Kościańska (red.), Kobiety i religie, Kraków 2006.

Unterman A., Żydzi. Wiara i życie, Warszawa 2002.

Wouk H., To jest mój Bóg. Judaizm: wiara, prawo, etyka, Warszawa 2002.

\section{Słowa kluczowe}

judaizm, rodzina żydowska, wychowanie, Talmud, przykazania, obowiązki religijne

22 Tamże, s. 192.

23 Tamże. 


\section{STRESZCZenie}

Podstawą żydowskiego życia społecznego jest rodzina, a założenie jej było w istocie pierwszym przykazaniem jakie Bóg dał człowiekowi. Dlatego też Talmud - jako główne źródło nauki w judaizmie strzeże nieustannie jej czystości i stabilności, a rodzicom udziela licznych wskazówek odnośnie wychowania ich potomstwa. Z treści Talmudu wywodzą się również cztery podstawowe wartości, które stanowią fundament życia rodzinnego i pozwalają na wypełnianie wzajemnych zobowiązań wewnątrz tej struktury.

Dom żydowskiej rodziny jest więc zarówno ośrodkiem życia religijnego, jak i miejscem wypełniania rytuałów. Jednak specyficznie inne pozycje zajmują w niej kobiety i mężczyźni, co widoczne jest na tle różnic w obrzędowości dotykającej momentu przyjścia na świat i włączenia we wspólnotę dzieci płci żeńskiej i męskiej.

Rodzina stanowi ponadto obszar konstruowania się ról, które odnoszą poszczególnych jej członków nie tylko do rzeczywistości społecznej, ale przede wszystkim definiują ich pozycję w życiu religijnym. Dlatego najważniejszym obowiązkiem rodziców jest przekazanie dzieciom dziedzictwa i tradycji, i tym samym włączenie ich w życie społeczności jako pełnoprawnych jej członków. Stąd też sumienne wypełnienie rodzicielskich obowiązków obarczone jest dodatkową odpowiedzialnością w stosunku do całej wspólnoty.

\section{UPBRINGING OF CHILDREN IN JEWISH SOCIETY IN THE WORLD OF RELIGIOUS ORDERS}

\section{Keywords}

Judaism, Jewish family, upbringing, Talmud, commandments, religious duties

\section{Summary}

The basis of Jewish social life is family; starting a family was in fact the first commandment which God gave to a human being. That is why Talmud, as the main source of religious knowledge in Judaism, constantly guards its purity and stability and offers Jewish parents numerous pieces of advice concerning upbringing of their children. Four elemental values of Judaism originate in Talmud as well. They are foundations of family life and enable family members to fulfill reciprocal duties inside this structure.

Therefore, Jewish family's home is not only the centre of religious life, but also the place of religious ceremonies. However, there are specific differences between the positions of women and men in a Jewish home. They are visible especially in rituals connected to birth and introducing male and female children to the society.

Family is additionally an area of constructing roles significant for its members not merely in their social environment, but above all in their religious lives. Consequently, the most important Jewish parents' responsibility is to transfer their heritage and tradition to their children and in this way introduce them to the life of society as its lawful members. That is the reason why dutiful fulfilling of parental obligations is burdened with increased responsibility towards the whole society. 